\title{
PREDICTION MODEL OF FIRM'S FINANCIAL DISTRESS
}

\author{
Lucia Svabova $^{1, a}$, Katarina Kramarova ${ }^{2, b, *}$ and Marek Durica ${ }^{3, c}$ \\ ${ }^{1}$ University of Zilina, Faculty of Operation and Economics of Transport and Communications, \\ Department of Economics, Univerzitna 8215/1, 01026 Zilina, Slovakia \\ ${ }^{2}$ University of Zilina, Faculty of Operation and Economics of Transport and Communications, \\ Department of Economics, Univerzitna 8215/1, 01026 Zilina, Slovakia \\ ${ }^{3}$ University of Zilina, Faculty of Operation and Economics of Transport and Communications, \\ Department of Quantitative Methods and Economic Informatics, \\ Univerzitna 8215/1, 01026 Zilina, Slovakia \\ alucia.svabova@fpedas.uniza.sk, bkatarina.kramarova@fpedas.uniza.sk, \\ cmarek.durica@fpedas.uniza.sk \\ *Corresponding author
}

Cite as: Svabova, L., Kramarova, K., Durica, M. (2018). Prediction model of firm's financial distress, Ekonomicko-manazerske spektrum, 12(1), 16-29.

Available at: dx.doi.org/10.26552/ems.2018.1.16-29

\begin{abstract}
The issue of classification of firms and the construction of a predictive model of their financial distress has long been in the focus of the attention of economists and scientists in different countries around the world. Since the 30's of the last century, they have been trying to create an economic model with a strong predictive ability or with a high degree of correct classification that, under the conditions of given country, could detect with a high level of reliability the financial distress or properly classify the company into a group of companies threatened by financial difficulties or bankruptcy. In case of Slovakia, the research of this area is being lacked. So far, some models have been presented to the professional public and, if it is necessary, it is rather preferred to use foreign prediction models. Their predictability, however, generally decreases under the conditions of the Slovak economy as they were created in another economic environment. Our model is based on the principles of the multivariate discriminant analysis, the first method of predicting bankruptcy. The presented model is relatively robust because it is based on real data from the financial statements of more than 30,000 enterprises for the year 2016 with the retrospective verification on data from the year 2015 and 2014. The model is generally applicable, it is not sector-oriented, and its discriminant function consists of financial indicators, which are clearly quantifiable. The model classifies enterprises as "prosperous" or as "unprosperous", where prosperous firms are in a good financial condition, and on the other hand, unprosperous firms are in the financial crisis, or are close to the bankruptcy. The model's primary objective is to identify a financial crisis correctly in order to adopt timely corrective actions by company's managers and shareholders or as a warning sign for external entities.
\end{abstract}

Keywords: prediction of default; bankruptcy prediction models; financial distress; multivariate discriminant analysis

JEL Classification: C38, G33 


\section{Introduction}

The financial-economic instability of the business sector entities leading to their failure is inherent to each economy, as well its consequences and remedies. Factors that cause this instability are different. They have features of either subjective or objective causes and their common feature is that they ultimately trigger restrictions on the firm's solvency. The financial instability or financial distress represents a term that describes the financial situation of the firm confronted with a temporary lack of liquidity and with the difficulties that ensue in fulfilling financial obligations on schedule and fully. If such situation is not properly solved, it could escalate in the long-term insolvency, in the worst case to the firm's own economic extinction. Since the effects of business failure can lead from financial losses up to society-wide problems, it is in the interest of firms, their shareholders, business partners, creditors, potential investors or state to identify such kind of risky firms. The identification of risky firms and the related forecasting of their financial health is realized through various techniques, methods, and postulates of so-called ex-ante financial analysis. The analysis is based on the assumption that a certain time before the financial failure the firm shows signs of financial crisis and by applying an appropriate method, it should be possible revealed such distress situation with the least degree of uncertainty as soon as possible. (Kramarova et al., 2015) In practice, the emphasis is also placed on the relative simplicity of the application of the prediction method, it should not be time-consuming and costly.

The literature that deals with the prediction ability of the financial analysis dates back to the early 30 's of the last century. In 1930, Smith published his univariate study that concerned the analysis of the predictive ability of selected financial indicators. The study concerned 29 financial ratios of the industry-oriented firms that during the years $1921-1927$ failed. The study of Fitzpatrick from 1932 is generally considered to be the first completed study aimed at identifying statistically significant differences between the prosperous and unprosperous firms. He applied univariate analysis using 13 financial indicators. Although the prediction power of the model was not proven statistically, the work is considered as pioneering. Among other authors of pioneering works belong e.g. Merwin, Chudson, Hickmen, Jackendoff, Tamari etc., stated by Kicova \& Kramarova (2013).

The study presented by beer in 1966 is considered as the end of the early period of the prediction of the firm's financial health based on the discriminant analysis. His work has popularized the use of the discriminant analysis in the process of creating of other predictive models. The models presented by Altman are considered to be ones of the best-known prediction models in the modern era of the prediction techniques. The first model presented in 1968 was designed to the manufacturing firms listed in the US capital market. The original set of financial indicators with a potential discriminant ability contained 20 financial ratios. The final discriminant function contains 5 of them. Altman in cooperation with other scientists has presented new prediction models that are known as Zeta or Z-models, according to Altman et al. (2014).

Nowadays, different methods of creating the prediction models are used, whether historically known methods of discriminant analysis and logistic regression, or even more modern methods of neural networks, genetic algorithms, classification trees, and random forests. For example, Jabeur \& Fahmi (2017) compared three models of predicting corporate financial distress of French companies created by discriminant analysis, logistic regression and random forests. The results showed that the best classification results gives the method of random forest. Jing \& Fang (2017) compared the logit model and data mining models in the field of prediction of bank failures in the USA. They found, that the logit model predicts bank failures less precisely than data mining models, but on the other hand, produces fewer missed failures predictions. Zikovic 
(2017) analysed, how time-varying variables and changes in the macroeconomic environment affect the probability of companies' financial distress in Croatia. In his study, discrete-time hazard models using logit were applied to demonstrate, that the probability of distress is influenced not only by firm-specific variables, but also by macroeconomic variables. Barkar (2017) developed models of crisis diagnostics for Russian companies renting commercial real estate. These models are created by discriminant analysis and logistic regression. Herman (2017) used the bootstrapping method and the multivariate discriminant analysis to compare prediction ability of models created for specific industry with general models created in Poland. The other aim of the research was to define determinants of joint-stock company bankruptcy in three particular industries of the Polish economy. Szetela et al. (2015) applied a multivariate discriminant analysis for differentiation among defaulted and non-defaulted nations. Their results indicated discriminant analysis as the most suitable method for insolvency prediction, compared to other methods like probit and logit model. Lohk \& Siimann (2016) prepared a model to predict the risk of encountering financial difficulties in Estonia by using discriminant analysis and logit analysis. Dima \& Vasilache (2016) focused their study to a credit risk modeling for prediction of default of companies operating in Romania. The estimations have been performed first using logistic regression, and then by Artificial Neural Networks method. Brozyna et al. (2016) applied linear discriminant analysis and logistic regression and furthermore classification trees and the method of nearest neighbours to analyse possible bankruptcy signals and to evaluate the financial condition of the selected sector, consisting of transport, spedition and logistics, for entities from Poland and Slovakia.

Several prediction models have in the last few years also been created in Slovakia. In addition to already known models of Gurcik (2002) and Chrastinova (1998), several authors have tried to create a prediction model with the best classification ability. Kovacova \& Kliestik (2017) developed models for bankruptcy prediction of Slovak companies by using logit and probit method and provide the comparison of overall prediction ability of the two developed models. Karas \& Reznakova (2017a) focused on the design of bankruptcy models, specifically the selection of suitable predictors to verify, whether bankruptcy predictors are industryspecific. Another objective of their research was to determine indicators, that are able to detect signs of bankruptcy earlier than one period before bankruptcy. They found, that application of industry-specific indicators and indicators that are able to detect signs of bankruptcy more than one year before, can help to increase the prediction accuracy of bankruptcy models for Slovak companies. In their another research paper, Karas \& Reznakova (2017b) developed prediction model for Slovak companies operating in the construction industry, by using the method of classification and regression trees. Gavurova et al. (2017) analyzed the impact of trend variables on the prediction ability of the models constructed using discriminant analysis and decision trees. They developed a new model for Slovak companies by using the decision tree technique. Mihalovic (2016) also dedicated his study to development of bankruptcy prediction models in Slovak Republic. The study is focused on the comparison of overall prediction performance of the two developed models: the first one is estimated via discriminant analysis, and another is based on a logistic regression. Feranecova \& Sabolova (2015) dedicated their analysis to construct an empirical prediction model for companies in the automotive industry by using discriminant analysis.

\section{Methodology and data}

The discriminant analysis is one of the oldest methods used for of objects statistical discrimination and the Fisher's linear discriminant analysis from 1936 is consider as its original 
version. Generally, the discriminant analysis is able to identify the ability of observed values to distinguish existing and beforehand known group of statistical units in the main file and formulate a classification rule that is used for allocation of new observation into these groups. Based on this, the discriminant analysis has two functions - descriptive function and prediction function. The canonical discriminant analysis focuses on its usage as a tool to describe the differences between two groups of prosperous and unprosperous firms. More often use of the discriminant analysis is because of its prediction function as classification of unknown firms into one of these groups. The discriminant criterion for assigning in the groups is presented as a function of the original variables, of which assumption is based on a choice of a set of firms, of which the corresponding group is known, stated by Valaskova et al. (2017).

In the financial analysis, the discriminant analysis is used mainly in the already mentioned ex-ante analysis. The main advantage of its application in this area is the fact that the findings drawn from the analysis are not influenced by the subjective opinions of the analysts and are considered to be exact, which preordains the discriminant models to be considered as the most widespread way of predicting the financial health of firms, stated by Snircova (2003), and Merkevicius \& Garsva (2007). The principle of applying the multivariate discriminant analysis in the field of analysis and evaluation of the financial health of firms lies in the best classification of the analyzed firm into the group of financial stable firms or into the group of financial unstable firms by using of one synthetic value - the dependent variable, which is a function of chosen financial indicators as explanatory variables.

The discriminant analysis, like other statistical methods, assumes that the statistical file of $n$ firms, which is characterized by $p$ financial indicators that are not linearly correlated to each other, has a multivariate normal distribution and that the multivariate standardization of the probability distribution of each group of firms applies, argue by Stankovicova \& Vojtkova (2007). It is recommended to test the equivalence of the covariance matrices in order to be possible to derivate the linear discriminant function. If the covariance matrices are not equal, it is possible to use rather the quadratic discriminant function, although in economic practice it is not very much used. If the equality of the matrices is confirmed statistically, then is recommended also to do the test of the mean values of the financial indicators within the classified groups. Between the classified groups of firms represented by the financial indicators should be statistically significant differences, which will ensure that the distance between the average value of the discriminant function of the group of prosperous firms and the discriminant function of the group of unprosperous firms is the largest.

\subsection{Creating of discriminant model for Slovak firms}

The process of creating our discriminant model designed for needs of the Slovak firms, we divided into several steps:

1. preparation of input data, determination of rules for "gross selection",

2. selection of financial indicators,

3. determination of rules for classifying the firms as "prosperous" and "unprosperous",

4. calculation of financial indicators,

5. verification of assumptions for the application of multivariate discriminant analysis,

6. creating of a multivariate discriminant model, verifying its discriminatory and prediction ability.

In each step, we used different scientific and mathematical-statistical methods. In the process of the discriminant analysis, we used IBM SPSS Statistics. 


\subsubsection{Preparation of input data}

The discriminant model of the prediction of the firm's financial health was created in the conditions of the Slovak economy based on data that could be found in the financial statements of selected firms in 2016. The financial statements were obtained from the Register of the Financial Statements of the Ministry of Finance of the Slovak Republic. We took into account just the financial statements of the firms that keep double-entry accounting according to the Section 9 (1) of the Act No. 431/2002 Coll. on Accounting as amended (thereinafter "Act on Accounting") and their financial statements have the character of ordinary financial statements. Since, according to the valid Slovak legislation, firms that keep double-entry bookkeeping prepare the financial statements according to their size classification (Section 2 (5) - (8) Act on Accounting), from the Register of the Financial Statements we downloaded data only those firms that draw up the financial statements for the small and large enterprises. In the process of database preparation, we eliminated firms that were classified as microenterprises and firms that prepared the financial statements according to the IFRS standards. These we excluded due to fact that their financial statements are not strictly prescribed by the law, it has only a recommended form and content, which may not provide the same data. In case of the microenterprises, the structure and content of their financial statements do not provide as detailed information as the financial statements for small and large enterprises. A large part of the items of these statements is cumulative items, which we considered limiting for the quantification of selected financial indicators and thereby, we excluded them from the database. On the other hand, it is important to note, that not all firms that were classified as microenterprises were excluded from the database. The reason is so, that the Slovak accounting legislative (Section 2 (12) Act on Accounting) allows these firms to draw up the financial statements for the small and large enterprises on a voluntary basis, which means that our database includes those firms, which took this opportunity. Another condition for the firms to be included into our database was the requirement for the continuity of their businesses from 2014 to 2016 . By fulfilling this condition, we obtained the necessary time series of data to create a model, as well as to verify its validity.

In this way, we created a database that contains data from the financial statements of 65,536 firms for the year 2016. In the next step of data preparation within the gross selection, we excluded firms which financial statements were not prepared correctly, i.e. their financial statements contained logical errors that could otherwise contribute to the distorting of the prediction model. To verify the correctness of the financial statements we used crosschecking of data. For instance, the condition of the equality of the total value of assets with liabilities and equity, equality of selected data in the balance sheet and in the profit and loss account, intergroup control of sums of the selected items of the assets, liabilities, equity, costs, and revenues, illogical values of quantified financial ratios (e.g. negative values of the liquidity ratios) etc. Finally, based on this crosschecking, i.e. based on the results of the gross and net selection (see following steps), the final version of database includes data from 30,613 financial statements.

\subsubsection{Selection of Financial Indicators}

The indicators used in the financial-economic analysis we consider to be the analysis's primary methodological postulates. We used only relative indicators (ratios), because unlike to absolute indicators, they are not sensitive to the size of an enterprise that is usually expressed as the book value of its assets. The suggested indicators we classified into four groups based on the area that they analyzed:

- liquidity indicators are indicators of whether firm's current assets (the potential of payments in monetary terms) will be sufficient to meet firm's short-term obligations; 
- activity indicators are used as measures to identify how effectively the firm uses its assets, in other words - capital that was used for their acquisition in achieving outputs, most commonly quantified in the form of sales or to assess the quality of suppliercustomer relationship;

- solvency indicators that are used to analyze firm's financial structure, degree of firm's dependence on liabilities and debts, as well the firm's debt-paying ability;

- profitability indicators analyze the firm's ability to generate earnings and be profitable.

The pilot draft of indicators contained from 28 ratios. We consider them basic and generally known indicators that are possible used as indicators of the financial stability and economic activity of any firm. Subsequently, we removed those indicators that did not have sense to quantify for the model's need. For instance, it was not possible to quantify them for a large number of firms included in the database, thus they lost their universal judgement ability (items from the financial statements that are included in the ratios `formulas, a large number of firms did not report). The final list of financial indicators includes 14 ratios - independent variables that stand out as predictors of the discriminant model. Their overview together with the classification and algorithm of the calculation we present in the Table 1.

Table 1: Selected Financial Indicators, Classification, and Algorithm

\begin{tabular}{|c|c|c|}
\hline Analyzed Area & $\begin{array}{l}\text { Indicator } \\
\text { Marking }\end{array}$ & Name of the Indicator and algorithm of the calculation \\
\hline \multirow{3}{*}{ Profitability } & $\mathrm{R} 1$ & Net Return on Assets $($ ROA EAT $)=$ EAT $/$ assets \\
\hline & $\mathrm{R} 2$ & Gross Return on Assets $($ ROA EBIT $)=$ EBIT $/$ assets \\
\hline & $\mathrm{R} 3$ & Net Return of Firm's Total Revenues $=$ EAT $/$ revenues \\
\hline \multirow[b]{2}{*}{ Activity } & A1 & Assets to Revenues Ratio $=$ assets $/$ revenues \\
\hline & A2 & $\begin{array}{l}\text { Current Assets to Revenues Ratio (without accruals and deferrals and long-term } \\
\text { liabilities) = current assets / revenues }\end{array}$ \\
\hline \multirow{4}{*}{ Liquidity } & L1 & $\begin{array}{l}\text { Cash Ratio = financial accounts / current liabilities including short-term accruals and } \\
\text { deferrals }\end{array}$ \\
\hline & $\mathrm{L} 2$ & $\begin{array}{l}\text { Quick Ratio }=(\text { financial accounts }+ \text { short-term receivables }) / \text { current liabilities } \\
\text { including short-term accruals and deferrals }\end{array}$ \\
\hline & L3 & $\begin{array}{l}\text { Current Ratio }=\text { (current assets }- \text { long-term receivables }+ \text { short-term accruals and } \\
\text { deferrals) / current liabilities including short-term accruals and deferrals }\end{array}$ \\
\hline & L4 & $\begin{array}{l}\text { Net Working Capital to Assets Ratio }=\text { (current assets }- \text { long-term receivables }+ \text { short- } \\
\text { term accruals and deferrals }- \text { current liabilities including short-term accruals and } \\
\text { deferrals) / assets }\end{array}$ \\
\hline \multirow{5}{*}{$\begin{array}{l}\text { Financial } \\
\text { Structure, } \\
\text { Solvency, } \\
\text { Indebtedness }\end{array}$} & $\mathrm{Z} 1$ & $\begin{array}{l}\text { Net Profit and Loss of Previous Year to Assets Ratio = net profit and loss of previous } \\
\text { year / assets }\end{array}$ \\
\hline & $\mathrm{Z} 2$ & Debt Ratio $=$ total liabilities including accruals and deferrals $/$ assets \\
\hline & $\mathrm{Z3}$ & $\begin{array}{l}\text { Current Debt to Assets Ratio = current liabilities including short-term accruals and } \\
\text { deferrals / assets }\end{array}$ \\
\hline & $\mathrm{Z} 4$ & Loans to Assets Ratio $=($ bank loans + bonds issued + financial assistance $) /$ assets \\
\hline & $\mathrm{Z5}$ & Equity to Debt Ratio = equity / total liabilities including accruals and deferrals \\
\hline
\end{tabular}

Source: own collaboration based on the literature research

\subsubsection{Rules for Classifying Firms as "Prosperous" and "Unprosperous"}

According to the Slovak legislation the term of financial distress can be identified with the definition "firm in the financial crisis" that is the situation, when the firm is in a danger of bankruptcy (it is found in the early stages of the financial crisis) or it is already in the state of 
bankruptcy. The first situation is usually solved by the informal restructuring, the second one by the judicial restructuring or by the bankruptcy.

The classification rules first of all take into account actual valid Slovak legislation - the Act No. 513/1991 Coll. on Commercial Code as amended (thereinafter "Commercial Code") where is the explanation of the term "firm in the financial crisis". It is a relatively new term in the Slovak legislation that was introduced by the amendment to the Commercial Code - the Act. No. 87/2015 Coll. with the effect from January 1, 2016. Its main aim is to ensure the protection of current creditors and to increase the level of responsibility of owners and members of a company's bodies for business. The legislation is applied only to a selected group of firms with a legal form of Limited Liability Company, Joint Stock Company, simple company for shares, and limited partnership, whose general partner is not a natural person. On the other hand, these types of companies are the most widespread forms of businesses in Slovakia.

Based on the official statistics in Slovakia up to 47,536 firms showed signs of the imminent bankruptcy in 2015 ( $26 \%$ of the total number of firms). The most of them were firms classified as micro enterprises (24,372); the rest represented firms classified as small and large enterprises, stated by Markova (2017). For the same period, a bankrupt was declared on 354 firms (407 in 2014) and to 92 firms judicial debts restructuring was allowed (115 in 2014), in Slovak Credit Bureau (2016).

The firm in the state of bankruptcy is regulated in accordance with the Section 3 of the Act No. 7/2005 Coll. on Bankruptcy and Restructuring as amended. Based on this legislation, the firm in bankruptcy is insolvent or the value of its equity is lower than total debts. The firm in a danger of financial failure is identified directly in the Commercial Code, Section 67a (2) - its equity to debt ratio is lower that 4:100 (the value of ratio that is valid for 2016), or 6:100 (for 2017), or 8:100 (since 2018). In terms of financial analysis, this ratio is a balance indicator of the degree of financial independence.

Besides the legislative parameters of the classification criteria, we determined also other criteria that in our opinion may indicate financial crisis of the firm or replace (approximate) legislative parameters that cannot be directly identified from the financial statements of the analyzed. Based on given facts, we determined the following classification criteria:

- The value of equity to debt ratio is lower than 0.04 . The value indicates the potential "dependence" from liabilities, decreasing level of the financial independence, and creditworthiness of the firm. If the value of the ratio is negative, the value of firm's equity is negative.

- The value of current ratio is lower than 1, which indicates that the firm is not able to cover existing short-term liabilities by its current assets, it has problems with the liquidity and generating of liquidity. If all short-term liabilities would be due, the firm would not have enough a security reserve of the short-term assets and would have to proceed to monetize part of the fixed assets to fulfill its liabilities.

- The earnings after taxes (EBIT) is negative, at most equal to zero. The indicator indicates that the firm is not able to generate profit that is considered to be the main source of corporate liquidity and the rate of return of all employed capital into business, regardless of their origin and ownership.

Based on these criteria, as the unprosperous firm was identified a firm that met conditions in case of all criteria. A prerequisite of the application of suggested classification criteria was an indisputable possibility of their quantification from the financial statements. 


\subsubsection{Quantification of Financial Indicators}

After the selection of financial indicators and determination of algorithms of their quantification, we started with their calculations. The values of some indicators within both sets of the firms (prosperous and unprosperous) statistically had the nature of extreme observations. Since such measurements may affect the characteristic of statistical data set, results of the statistical testing, incorrect selection and application of the statistical methods together with their explanatory power as well the quality of the prediction model, the firms - outliers that "suffered" from these values were eliminated within the process of the net selection. In this process, we applied two mathematical-statistical approaches. First, we focused on the value of each variable - each financial indicator, and secondly we analyzed the existence of multivariate outliers with respect to the combination of values of all indicators for all firms.

In the first approach, for each independent variable, to further analyses we included the indicators, which values were in 2.2 times in their quartile spread, according Hoaglin \& Iglewcz (1987). Within the second approach, we identified multidimensional outliers using the Mahalanobis distance according to Tabachnick \& Fidell (2013).

\subsubsection{Verification of Assumptions for Application of Discriminant Analysis}

After the data preparation needed as inputs for the discriminant model, we focused on verifying the validity of assumptions required to apply the discriminant analysis. In assessing the suitability of the variables, we proceeded from the well-known assumption that suitable discriminators would be those financial indicators whose values would be statistically significant different within the group of the prosperous and unprosperous firms. This characteristic, we examined by applying the variance analysis. We also consider this analysis to be enough robust because of sufficient sample size - the final number of the firms after the gross and net selection processes despite the fact that the assumption of the normal distribution of the sample data was not examined.

\subsubsection{Creating Multivariate Discriminant Model, Verifying of Prediction Ability}

This step involves compiling of the discriminant model's function that classifies the firms as prosperous or unprosperous including verifying the discriminant ability of all financial ratios that compose the function. The ability of the prediction model to classify the firms correctly, we verified on the original sample of data as well as on a sample of randomly selected firms in 2015 and 2014.

\section{Results}

As we have mentioned above, the prediction model of financial health of firms was composed on the base of data from the financial statements of 30,613 firms compiled for the year 2016. The firms, considering our classification criteria, were classified into following groups:

1. group - ,prosperous firms“ (in dataset marked as 0) includes 28,295 firms (92, 43\%),

2. group - „unprosperous firms“ (in dataset marked as 1) includes 2,318 firms $(7,57 \%)$.

The descriptive statistics of all financial indicators for both groups of the firms is shown in the Table 2.

Within the measured values of the financial indicators for the group of prosperous firms, the highest degree of variability we identified in case of the equity to debt ratio $Z_{5}$. The minimal value of the financial indicator was even negative within this group that points to the fact that some of the firms had negative values of their equity and their businesses and operative 
activities were financed thanks to liabilities. This financial indicator is also one of the suggested classification criteria. If we took into account only this classification criterion, like the Slovak legislation, the firms marked as prosperous would be classified as unprosperous, despite the fact that our criteria did not classify the firms such a way. ${ }^{1}$ In the case of the group of unprosperous firms, the highest variability was identified in the case of the assets to revenues ratio $\mathrm{A}_{1}$.

Table 2: Descriptive Statistics of the Financial Indicators for the Group of the Prosperous Firms and For the Group of Unprosperous Firms

\begin{tabular}{|c|c|c|c|c|c|c|c|}
\hline \multicolumn{2}{|c|}{$\begin{array}{l}\text { Financial Indicator (independent } \\
\text { variable) }\end{array}$} & \multirow{2}{*}{$\begin{array}{l}\text { Average } \\
\text { Value } \\
0.07\end{array}$} & \multirow{2}{*}{$\begin{array}{l}\text { Median } \\
0.05\end{array}$} & \multirow{2}{*}{$\begin{array}{l}\text { Dispersion } \\
0.01\end{array}$} & \multirow{2}{*}{$\begin{array}{l}\text { Standard } \\
\text { Deviation }\end{array}$} & \multirow{2}{*}{$\begin{array}{l}\text { Min. } \\
\text { Value } \\
-0.35\end{array}$} & \multirow{2}{*}{$\begin{array}{l}\text { Max. } \\
\text { Value } \\
0.46\end{array}$} \\
\hline $\mathrm{R} 1$ & prosperous & & & & & & \\
\hline & unprosperous & -0.10 & -0.08 & 0.01 & 0.09 & -0.35 & 0.00 \\
\hline \multirow[t]{2}{*}{$\mathrm{R} 2$} & prosperous & 0.11 & 0.08 & 0.02 & 0.13 & -0.36 & 0.56 \\
\hline & unprosperous & -0.08 & -0.06 & 0.01 & 0.09 & -0.34 & 0.41 \\
\hline \multirow[t]{2}{*}{ R3 } & prosperous & 0.04 & 0.03 & 0.01 & 0.08 & -0.30 & 0.36 \\
\hline & unprosperous & -0.08 & -0.05 & 0.01 & 0.07 & -0.30 & 0.00 \\
\hline \multirow[t]{2}{*}{ L1 } & prosperous & 0.67 & 0.35 & 0.68 & 0.83 & 0.00 & 4.02 \\
\hline & unprosperous & 0.16 & 0.09 & 0.04 & 0.19 & 0.00 & 0.98 \\
\hline \multirow[t]{2}{*}{$\mathrm{L} 2$} & prosperous & 1.39 & 1.07 & 1.28 & 1.13 & 0.00 & 6.76 \\
\hline & unprosperous & 0.46 & 0.45 & 0.08 & 0.29 & 0.00 & 1.00 \\
\hline \multirow[t]{2}{*}{ L3 } & prosperous & 1.67 & 1.28 & 1.45 & 1.21 & 0.00 & 7.42 \\
\hline & unprosperous & 0.62 & 0.65 & 0.07 & 0.26 & 0.00 & 1.00 \\
\hline \multirow[t]{2}{*}{ L4 } & prosperous & 0.15 & 0.16 & 0.13 & 0.36 & -1.74 & 1.72 \\
\hline & unprosperous & -0.44 & -0.36 & 0.12 & 0.35 & -1.74 & 0.00 \\
\hline \multirow[t]{2}{*}{$\mathrm{Z} 1$} & prosperous & 0.08 & 0.06 & 0.07 & 0.27 & -0.90 & 0.95 \\
\hline & unprosperous & -0.22 & -0.13 & 0.06 & 0.25 & -0.90 & 0.30 \\
\hline \multirow[t]{2}{*}{$\mathrm{Z} 2$} & prosperous & 0.64 & 0.65 & 0.08 & 0.28 & 0.10 & 1.94 \\
\hline & unprosperous & 1.20 & 1.12 & 0.05 & 0.23 & 0.96 & 2.19 \\
\hline \multirow[t]{2}{*}{$\mathrm{Z} 3$} & prosperous & 0.57 & 0.56 & 0.08 & 0.28 & 0.00 & 1.92 \\
\hline & unprosperous & 1.12 & 1.07 & 0.08 & 0.28 & 0.03 & 2.15 \\
\hline \multirow[t]{2}{*}{$\mathrm{Z4}$} & prosperous & 0.03 & 0.00 & 0.00 & 0.05 & -0.14 & 0.21 \\
\hline & unprosperous & 0.02 & 0.00 & 0.00 & 0.05 & -0.14 & 0.21 \\
\hline \multirow[t]{2}{*}{$\mathrm{Z5}$} & prosperous & 1.01 & 0.54 & 1.48 & 1.22 & -0.48 & 6.13 \\
\hline & unprosperous & -0.14 & -0.11 & 0.02 & 0.14 & -0.54 & 0.04 \\
\hline \multirow[t]{2}{*}{ A1 } & prosperous & 0.80 & 0.58 & 0.47 & 0.69 & -1.10 & 4.65 \\
\hline & unprosperous & 0.96 & 0.70 & 0.69 & 0.83 & 0.02 & 4.65 \\
\hline \multirow[t]{2}{*}{ A2 } & prosperous & 0.50 & 0.38 & 0.16 & 0.40 & -0.91 & 2.50 \\
\hline & unprosperous & 0.55 & 0.41 & 0.22 & 0.47 & 0.00 & 2.49 \\
\hline
\end{tabular}

Source: own collaboration (SPSS)

${ }^{1}$ Note: Some experts draw attention to the strictness of this legislative categorization without taking into account other facts that characterize the current financial and economic performance of a firm. 
In the case of both groups, the debt ratio $\mathrm{Z}_{4}$ showed the lowest degree of the variability ${ }^{2}$. The largest distance between the average vales of the financial indicators of both groups was identified in the case of the equity to debt ratio $Z_{5}$. after that in the case of the current ratio $\mathrm{L}_{3}$. and quick ratio $\mathrm{L}_{2}$. The financial ratio of the current liquidity $\mathrm{L}_{3}$ is also one of our classification criteria and its critical value was set at one. Its average value in case of the group of prosperous firms was above this value (1.67), and in the case of unprosperous firms was below this value (0.62).

All of the applied financial indicators were relevant for using in the prediction model. which was confirmed by the $t$-test of the mean values. Their discriminant ability is confirmed because of significant difference between the mean values for both groups of the firms (p-values Sig (2tailed) were lower than 0.05 for all financial indicators).

Table 3: T-test of the Mean Values

\begin{tabular}{llllll}
\hline \multicolumn{5}{c}{ Levene's Test for Equality of Variances } & t-test for Equality of Means \\
\cline { 2 - 6 } & F & Sig. & t & df & Sig. (2-tailed) \\
R1 & 35.518 & & & & \\
R2 & 246.791 & 0 & 88.344 & $2,928.232$ & 0 \\
R3 & 11.863 & 0 & 93.134 & $3,183.767$ & 0 \\
L1 & $1,691.29$ & 0.001 & 75.744 & $2,784.448$ & 0 \\
L2 & $1,384.992$ & 0 & 81.261 & $12,556.675$ & 0 \\
L3 & $1,595.028$ & 0 & 102.736 & $10,713.229$ & 0 \\
L4 & 0.038 & 0 & 116.333 & $13,776.066$ & 0 \\
Z1 & 12.52 & 0.846 & 76.046 & 30,611 & 0 \\
Z2 & 215.978 & 0 & 54.56 & $2,764.305$ & 0 \\
Z3 & 90.552 & 0 & -110.273 & $2,891.842$ & 0 \\
Z4 & 15.993 & 0 & -89.209 & $2,704.11$ & 0 \\
Z5 & $2,253.623$ & 0 & 2.569 & $2,748.996$ & 0.01 \\
A1 & 138.179 & 0 & 147.364 & $29,055.951$ & 0 \\
A2 & 103.364 & 0 & -9.062 & $2,582.577$ & 0 \\
\hline
\end{tabular}

Source: own collaboration (SPSS)

The discriminant function by applying of all financial indicators was compiled in accordance with the theoretical background of the canonical discriminant analysis. The test statistic Wilks` Lambda. its results are in the following Table 4 . The value of the canonical correlation is 0.608 that indicates a moderate correlation between the canonical function and independent variables. The resulting discriminant function is given by

$$
\begin{aligned}
& Z-\text { score }=-10.854 \cdot R 1+8.451 \cdot R 2-3.970 \cdot R 3+0.116 \cdot L 1+0.085 \cdot L 2+ \\
& 0.074 \cdot L 3-0.772 \cdot L 4+0.316 \cdot Z 1+3.684 \cdot Z 2+1.052 \cdot Z 3+0.611 \cdot Z 5+0.047 \\
& A 1+0.174 \cdot A 2-4.086
\end{aligned}
$$

\footnotetext{
${ }^{2}$ Note: The debt ratio showed negative values in the case of some firms, which is caused by the valid accounting legislation that except other regulates reporting of assets, equity and liabilities (the item is reported as a part of liabilities, however with minus sign).
} 
Table 4: The Values of the Canonical Correlation and test of Statistical Significance

\begin{tabular}{lllll}
\hline Eigenvalues & & & & \\
\hline \multirow{2}{*}{ Function } & Eigenvalue & $\%$ of & Cumulative & Canonical \\
& & Variance & $\%$ & Correlation \\
1 & 0.587 & 100 & 100 & 0.608
\end{tabular}

First 1 canonical discriminant functions were used in the analysis.

Wilks' Lambda

$\begin{array}{llll}\text { Test of Function(s) } & \text { Wilks' } & \text { Lambda } & \text { Chi-square df }\end{array}$

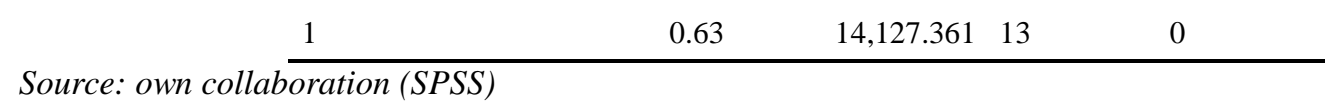

The coefficients in equation (1) are used to calculate the Z-score for each firm. The value of the Z-score of the firm is compared then with the weighted average of the centroids of both groups of the firms that allows us to identify the firm's group membership. Since we used the canonical distribution function of the Z $Z$-score with the constant value, it will be enough to compare the value of the Z-score with zero. The negative value of the $\mathrm{Z}$-score indicates that the firm belongs to the group of prosperous firms; the positive value of the Z-score indicates that the firm belongs to the group of unprosperous firms.

\section{Discussion}

The final discriminant function of our prediction model. by which we will decide whether the firm will belong among the prosperous or unprosperous firms, is given by (1). The analyzed firm will be included into the group of prosperous firms. if its $Z-$ score $<0$. If the $Z-$ score $>0$. the firm will be classified as unprosperous.

From the discriminant function of our model follows that the profitability financial indicators $\mathrm{R}_{1}$ and $\mathrm{R}_{2}$ are independent variables with the highest discriminant ability. On the other hand. the financial indicator $A_{1}$ and surprisingly $L_{3}$ (one from our classification criteria) have the lowest discriminant ability. Based on the coefficient of correlation between the financial indicators and the discriminant function. the strongest discriminating variables are financial indicators $Z_{2}$ and $Z_{3}$. while both are positive correlated with the discriminant function.

According to retrospective verification of the model on the original data file (data for 2016). the model correctly marked $91.9 \%$ of the firms that were included into the group of prosperous firms. and $92.3 \%$ of firms that were included into the group of unprosperous firms (Table 5).

Table 5: Classification Table of Model for Original Sample

\begin{tabular}{|c|c|c|c|c|c|}
\hline \multirow{2}{*}{\multicolumn{3}{|c|}{ Classification Results }} & \multicolumn{2}{|c|}{ Predicted Group Membership } & \multirow[t]{2}{*}{ Total } \\
\hline & & & 0 & 1 & \\
\hline \multirow{4}{*}{ Original } & \multirow{2}{*}{ Count } & 0 & 26,112 & 2,183 & 28,295 \\
\hline & & 1 & 188 & 2,130 & 2,318 \\
\hline & \multirow{2}{*}{$\%$} & 0 & 92.3 & 7.7 & 100 \\
\hline & & & 8.1 & 91.9 & 100 \\
\hline \multicolumn{6}{|c|}{$92.3 \%$ of original grouped cases correctly classified. } \\
\hline
\end{tabular}

Source: own collaboration (SPSS)

Its discriminant ability is $91.2 \%$, totally and thereby we consider the model as model with good discriminant ability. 
We also verified the functionality of our model based on $1 \%$ of sample of randomly chosen firms in 2014 and 2015. The results of the verification for 2014 show that our model correctly classified $92.3 \%$ of the firms that were included into the group of unprosperous firms, in case of the group of prosperous firms the model correctly classified $70.3 \%$ of firms. In 2015 , the model correctly marked $92.3 \%$ of the firms that were classified into the group of unprosperous firms, and $74.3 \%$ of the firms that were a part of the group of prosperous firms. Based on the results, we can state that the discriminant ability of the model within the group of firms classified as prosperous in 2015 and 2014 decreased. The index of total discriminant ability of the model reached $83.3 \%$ in 2015, and $81.3 \%$ in 2014, which represents a significant ability of the model of correct classification of the firm respectively prediction of firm's financial health. Because the model was purposefully created for the needs of classification of risky firms, we can state, that decreasing ability to correctly classify financially healthy firms is not an abstacle in the application of the model. The priority is that, in the event of a financial crisis, the model should be able to detect these difficulties with a high degree of reliability, which in the case of the discriminant model means the ability to correctly classified unprosperous firms as really unprosperous.

On the other hand, as the disadvantage and lack of the model may be seem its "general" focus or the fact that it is based on purely accounting data; it does not take into account any qualitative data such as the classification of overdue receivables and liabilities or based on their subordination, the existence of useable stock. the objectivity of differences from revaluation. the ability to create real cash flow, either market (capital) data.

The generality of the model may be an obstacle in the sense that the selected financial indicators used as explanatory variables in the prediction modelling, are, according to several authors, sector-specific, especially the indicators of activity and profitability, according to studies Cisko \& Kliestik (2013), Kicova \& Kramarova (2013), Kollar et al. (2015), and Zallai (2016).

The liquidity ratios do not often describe the real payment ability, because their formulas do not take into account for instance the quality of receivables, quality of the stocks and financial assets mainly in relation to their marketability. If the firm creates to them adequate value adjustments, the values are matched to reality and such kind of accounting items may be considered as credible. Alternatively, we recommend using so-called structured liquidity indicators in the process of financial analysis, because they are able to consider the transformation process of the current assets into earnings. In our model, we partially corrected these negative characteristics of the liquidity indicators by the inclusion of the net working capital to assets ratio. The net working capital. which is considered a reserve of the firm's liquidity, it is in the ratio to the size of firm, which is mainly expressed through the book value of assets. Together with other liquidity indicators creates a multidimensional view on the firm's liquidity, which enhances the diagnostic ability of the liquidity analysis.

Regarding the indicators of indebtedness, we see the relative reserve in the case of the net profit and loss of previous year to assets ratio. Net profit and loss of previous year represent a retention profit that is influenced not only by the ability of the firm to be profitable in the long run. but also by the management approach in the field of dividend policy and the way of dealing with the reported profit. In the area of the activity analysis, as the problem we see mainly the realistic value of used inputs - it means assets and their components. The indicators themselves are in practice "artificially" influenced by the applied valuation methods, by choice of a depreciation policy (accelerated contra linear depreciation), and by inflation. The indicators from this area are often consider as specific for individual industry sectors. 
Regarding the ability of the firm to generate real cash flows, it is not taken into account in the model mainly due to fact that not all firms that are included into the database are required to compile cash flow statement. Similarly, this also applies in the case of market indicators they were not considered due to relatively small volumes of traded titles on the Slovak capital market.

\section{Conclusion}

In the article, we presented the prediction model of financial health of firms together with the methodology of its creating. It is a prediction model respectively classification model, by which is possible to classify the analyzed firm as prosperous or unprosperous. The model is based on the principles of the canonical discriminant analysis and it is primarily designed for the evaluation and prediction of financial health of firms that operate in the Slovak economic environment. We consider the model itself as relatively robust as it was built on data from up to 30.316 firms. The discriminant function of the model consists of 14 financial indicators. The indicators reflect the financial stability and economic activity of any business entity and are clearly quantifiable based on the available financial statements.

Based on the coefficients of the independent variables, the financial indicators of profitability $R_{l}\left(\mathrm{ROA}_{\mathrm{EAT}}\right)$ and $R_{2}\left(\mathrm{ROA}_{\mathrm{EBIT}}\right)$ have the highest discriminant ability. Based on the coefficients of correlation between the independent variables and discriminant function, the strongest discriminant variables are $Z_{2}$ (debt ratio) and $Z_{3}$ (current debt to assets ratio).

The model was created on the base of data from 2016 and the retrospective verification on the original sample showed that its total classification ability is $91.2 \%$. It means that the model from 100 firms classified as the prosperous firms incorrectly marked 8 of them, and 8 from the group of firms classified as unprosperous. The discriminant model's ability was tested also on a random sample of $1 \%$ of the firms from the database for 2015 and 2014 . The results of this ex-post verification show that total index of model's discriminant ability reached the value 83.3 $\%$ in 2015 , and 81.3 per cent in 2014. Based on the results we can state that our discriminant model of the prediction of financial health of firms shows significant ability of correct classification of the analyzed firm and prediction of its financial health. On the other hand. as the model's disadvantage may be consider its "general" focus. However, the existing database based on which the model was made, offers also information about the industry classification of the firms based on their NACE codes and thus creates a space for creating special-oriented prediction models. which would be sector-oriented.

\section{Acknowledgements}

This work was supported by the Slovak Research and Development Agency under Grant number APVV-14-0841: Comprehensive Prediction Model of the Financial Health of Slovak Companies.

\section{References}

Act No. 7/2005 Coll. on Bankruptcy and Restructuring.

Act No. 513/1991 Coll. on Commercial Code.

Altman, E.I., Iwanicz-Drozdowska, M., Laitinen. E.K. \& Suvas, A. (2014). Distressed Firm and Bankruptcy Prediction in an International Context: A Review and Empirical Analysis of Altmans Z-Score Model. SSRN Electronic Journal, doi:10.2139/ssrn.2536340.

Barkar, A.A. (2017). Development of Instruments of Financial Diagnostics of Crisis. St Petersburg University Journal of Economic Studies, 33(4), 658-672. 
Brozyna, J., Mentel, G. \& Pisula, T. (2016). Statistical Methods of the Bankruptcy Prediction in the Logistics Sector in Poland and Slovakia. Transformations in Business \& Economics, 15(1), 93-114.

Chrastinova, Z. (1998). Metody Hodnotenia Ekonomickej Bonity a Predikcie Financnej Situacie Polnohospodarskych Podnikov. Bratislava. Slovakia: VUEPP.

Cisko, S. \& Kliestik, T. (2013). Financny Manazment Podniku II. Zilina. Slovakia: EDIS Publishing.

Dima, A. M. \& Vasilache, S. (2016). Credit Risk Modeling for Companies Default Prediction Using Neural Networks. Romanian Journal of Economic Forecasting, 19(3), 127-143.

Feranecova, A. \& Sabolova, M. (2015). Utilization Discriminant Analysis to Predicting Financial Situation Companies in the Automotive Industry. Conference Proceedings of the 2nd International Multidisciplinary Scientific Conference on Social Sciences and Arts SGEM2015.

Gavurova, B., Janke, F., Packova, M. \& Pridavok, M. (2017). Analysis of Impact of Using the Trend Variables on Bankruptcy Prediction Models Performance. Ekonomicky casopis, 65(4), 370-383.

Gurcik, L. (2012). G-index - the Financial Situation Prognosis Method of Agricultural Enterprises. Agricultural Economics, 48(8), 373-378.

Herman, S. (2017). Industry Specifics of Joint-Stock Companies in Poland and Their Bankruptcy Prediction. Conference Proceedings of the 11th Professor Aleksander Zelias International Conference on Modelling and Forecasting of Socio-Economic Phenomena. Cracow, Poland: 93-102.

Hoaglin, D. C. \& Iglewicz, B. (1987). Fine-Tuning Some Resistant Rules for Outlier Labeling. Journal of the American Statistical Association, 82(400), 1147-1149.

Jabeur, S. B. \& Fahmi, Y. (2017). Forecasting Financial Distress for French Firms: A Comparative Study. Empirical Economics, 54(3), 1173-1186.

Jing, Z. \& Fang, Y. (2017). Predicting US Bank Failures: A Comparison of Logit and Data Mining Models. Journal of Forecasting, 37(2), 235-256.

Karas, M. \& Reznakova, M. (2017a). The Stability of Bankruptcy Predictors in the Construction and Manufacturing Industries at Various Times Before Bankruptcy. E+M Ekonomie a Management, 20(2), 116133.

Karas, M. \& Reznakova, M. (2017b). Predicting the Bankruptcy of Construction Companies: A CART-Based Model. Engineering Economics, 28(2), 145-154.

Kicova, E. \& Kramarova, K. (2013). Possibilities of Using Financial Analysis on ohe Bus Transport Companies. Conference Proceedings of the 9th International Scientific Conference Financial Management of Firms and Financial Institutions. Ostrava, Czech Republic: 332-341.

Kollar, B., Kramarova, K. \& Valaskova, K. (2015). The Financial Distress Analysis of the Stated-Own Company by Applying Chosen Default Prediction Models in Condition of Slovakia. Conference Proceedings of the 3rd International Conference on Economics and Social Science (ICESS 2015). Bellflower, USA: 160-167.

Kovacova, M. \& Kliestik, T. (2017). Logit and Probit Application for the Prediction of Bankruptcy in Slovak Companies. Equilibrium. Quarterly Journal of Economics and Economic Policy, 12(4), 775-791.

Lohk, P. \& Siimann, P. (2016). Predicting the Risk of Encountering Financial Difficulties by the Example of Estonian Municipalities. Conference Proceedings of the 5th International Conference on Accounting. Auditing. and Taxation (ICAAT 2016). Paris, France: 297-306.

Markova, J. (2017, May 16). Ako si preverit svojho obchodneho partnera. Lecture. Retrieved June 22. 2018. from http://www.sario.sk/sites/default/files /files/Spoločnost'v kríze_16.5_2017.pdf

Merkevicius, E. \& Garsva, G. (2007). Prediction of Changes of Bankruptcy Classes with Neuro-Discriminate Model Based on the Self-Organizing Maps. Information Technology and Control, 36(1), 145-151.

Mihalovic, M. (2016). Performance Comparison of Multiple Discriminant Analysis and Logit Models in Bankruptcy Prediction. Economics \& Sociology, 9(4), 101-118.

Slovak Credit Bureau, (2016. January 18). Pocet spolocnosti v upadku na Slovensku bol vlani najnizsi od zaciatku

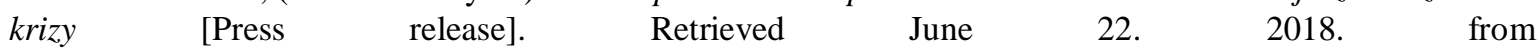
https://www.crif.sk/Novinky/Novinky/Documents/TS_CRIF_SK_Konkurzyrestrukturalizaciev roku 2015.pdf

Snircova, J. (2003). Financial Health Indicators for Prediction Models of Slovak Firms' Financial Situation. Ekonomicky casopis, 51(9), 1127-1145.

Stankovicova, I. \& Vojtkova, M. (2007). Viacrozmerne Statisticke Metody s Aplikaciami. Bratislava. Slovakia: Iura Edition.

Tabachnick, B. G. \& Fidell, L. S. (2012). Using Multivariate Statistics (6th ed.). Boston: Pearson/Allyn \& Bacon. Valaskova, K. Svabova, L. \& Durica, M. (2017). Verifikacia Predikcnych Modelov v Podmienkach Slovenskeho Polnohospodarskeho Sektora. EMI (Economics Management Innovation), 9(3), 30-38.

Zalai, K. (2016). Financno-ekonomicka Analyza Podniku (9th ed.). Martin. Slovakia: Sprint 2. 